\title{
How to Motivate the Students through the Communication
}

\author{
Gentjana Panxhi \\ PhD Candidate, Lecturer of the Faculty of Education \\ University "Alexander Moisiu", Durres, Albanıa \\ Email: genta_panxhi@yahoo.com
}

\section{Doi:10.5901/mjss.2013.v4n11p499}

\begin{abstract}
The primary objective of this paper is to identify how much is the influence of the communication in the results of school teacher. Considering the communication as a part and parcel of not only the personal lives of people, but also of the professional, formative, and educational processes, etc ... It is necessary to stress that the study and the observation of communication is an important element of the educational process. Not only in its use of different techniques, but also as an important means to encourage and motivate the students to achieve the best results not only cognitive, but also affective ones. But is it possible to motivate someone to do something or to achieve the highest possible results? And everyone who is and feels responsible for the good of others has surely asked that question to himself. Although the motivation is an inner pressure that each one must find inside himself or herself, however, it is possible to help a student to find the right stimulation (pressure) to attain the highest possible results. But words alone cannot be enough to stimulate encouraging, ways of organizing in a more motivational or communication way. We must first recognize and analyze types (styles) of thinking and learning at each of the students to motivate each of them in the most optimal way possible. The motivational communication should serve to find a vision, and also to give that vision stimulating and encouraging the students to achieve the appropriate objectives.
\end{abstract}

Keywords: communication, motivation, students, objectives, etc.

\section{Introduction}

We should consider communication not merely as part and parcel of the human life either the personal or the profesional one but also as an important and essential element of the process of education. We have three types of communications : the verbal, the non verbal and especially the preverbal one. They constitute an union of phenomena leading into the transmition of the information. At the same time the pupils must be well motivated to aim at achieving high value targets not only cognitive but also affective ones during the learning process.As Mr. Dornyei ${ }^{1}$ puts it ;Without a sufficient motivation even able individuals can not achieve long term goals or the appropriate curricula and even an appropriate teaching is not enough to bring about the success of the pupils. On the other hand a strong motivation can serve as compensation for a considerable lack of the language skills or the learning conditions.

\section{The realisation of the pre conditions to the motivation of the pupils.}

In order to fulfil the aim of learning, it is a must the collaboration, the intercourse and especially the communication between both parties (the teacher and the pupils). We should consider the importance of the communication between both parties not just as a bridge of physically coming closer, but also psychologically and even more emocionally in order to better understand their needs and interests. The teacher should be efficient but he or she also should establish fruitful reciprocal relations with all his pupils. To the teacher it is not important only the communicatioin but also the way this communication is realised. The teacher uses his voice as a vehicle of communication. He also uses his body language, his thoughts, his cognition, his knowledge, his emotional stance etc.

The communication and the motivation of the class by the teacher should be a sustainable one regarding the pupil not only during the school hours but also beyond them. First of all the teacher should bulldoze his pupils into quiting such bad habits regarding learning as :learning is not important or useful to us(the pupils), or to spend as less time as possible

${ }^{1}$ Dörnyei, Z. (2005), The psychology of the language learner. Individual differences in second language acquisition, Routledge, NewYork \& London 
learning the school subjects, or to pay less attention to their psycho-fisical wellbeing etc. it is also advisible not to study while being exposed to influences harmful to the concentration of the pupil. It should stimulate in the pupils :

- Emotional control

- Their self consciousness of their abilities

- They should be self counscious

- $\quad$ They should be prone to learning

- They should be able to process information

\section{Communication, a means in increasing motivation based on the needs of the pupils.}

The pupil during the class should not only listen to what his teacher is saying, but he also should be motivated to be an active part of the learning process. What the pupils learn should meet their needs and should resist the test of the time. What the primary school pupils learn should remain with them for their whole life. Thus it is of primary importance to set up the conditions to the pupils especially primary education ones to incite motivation, love and joy for learning, for acquiring new knowledge. As Bruner ${ }^{2}$ put it : The will of learning is expressed as curiosity, a love for competences, a need for self identification, a need for reprocity. Curiosity is one of the traits of being human, and especially of the children, who are born with the desire to be curious, with the eagerness to cognize, as their exploratory activities of the reality witness, the things they are interested about, the questions they ask continuously etc. etc. The teacher does not merely answers to the questions of the pupils but also he motivates his pupils through his communication not just to accumulate information. No they should also be able to draw conclusions from the facts they are aware of , and he should also be able to properly use his information in order to resolve the problems he come accross. The pupil should be able to search for sound sources of information for his own use. The teacher through his communication should not make use only of the curiosity of the pupil, he should also exert pressure on the desire of the pupils for more competences i.e.in the inborn need to be able to execute activities. Well,it is a common knowledge that the pupils are most interested in the things they accomplish well and they easily give up those activities where the desired success is not achieved.

It is the duty of the teacher to use his or her communication in order to set up favorable situations for the pupils so that all of them or at least the majority of them achieve the success. Precisely this achievement of the success influences the increase in the motivation of the pupils to continue their involvement in this learning process. Thus the achieved success strengthens the motivation and paves the way for more successes down the road of learning. The positive image of himself induces the pupil to commit himself more and more in the learning process. The lack of success simply demotivates the pupil. Brunner ${ }^{3}$ also stresses the need for self identification i.e. the strong tendency of the people to identify themselves and their aims with models offered by another individual, especially offered by the parents or the teachers as those are quite substancial figures(charactes) to the pupils. That's why the teacher should always beam positive qualities and values resulting from his knowledge and know how, which are passed over to and imprinted to the other individuals, so that they can self-analyze and self-esteem their situation aiming at the improvement of such a situation. Anyway at school we can rely also on what Bruner calls reciprocal need i.e.To duly meet the expectations of the others towards us.

\section{Which are the best ways to motivate the pupils through the motivating communication of the teacher?}

The teacher in order to motivate the pupils of his class can decide to communicate and to transfer the knowledge and know how in a group manner (collectively), provided that there are no great differences in the intelectual and emotional capacities of the pupils of this class. Thus it is possible to meet the assigned targets by the class as a whole. Normally this would be quite an achievement for everybody in the class. This becomes quite impossible, when there are social, psychological emotional and intelectual differences among the pupils of the class. The pupils who are less bright, more timid, who need more time to process and assimilate the knowledge imparted to them, feel themselves uneasy. Such a thing surely would have a negative impact on the results of this group of pupils. In order to avoid such difficult situations, the teacher should create a more flexible environment focusing on smaller groups sharing similiar characteristics and demands, which might feel themselves marginalized, thus enabling them to acquire positive knowledge and emotions

\footnotetext{
2 Bruner J.S., Verso una teoria dell'istruzione, Armando, Roma, 1967

${ }^{3}$ Bruner J.S., Verso una teoria dell'istruzione, Armando, Roma, 1967
} 
during the learning process. In order to achieve such a target it is indispensable that these groups members should shed the feeling of difficulties as they are members of a smaller group, i.e. It is easier for them to face a smaller number of other pupils sharing almost the same level of abilities and capabilities, the same pace of processing and assimiliating of knowledge of the learning process. This does not necessary mean that these groups would leg behind the rest of the class. Simply it would be easier for the teacher to deal with such restricted groups consisitng of pupils more or les of the same level of knowledge and abilities. Ity would be easier for the teacher to select and adopt the needed means of communication in order to motivate these pupils on the bases of their specific characteristics and needs.

\section{Conlusions}

We can conclude that it is the teacher the one who selects the appropriate form of communication and motivation of his or her pupils, as it is him the one who knows best the specific needs of his pupils. In case that the classes of the primary education will consist of pupils or big groups of pupils sharing the same characteristics and needs, it would be easier for the teacher to find the appropriate motivating communication and to establish a common stimulating vision. Unfortunately, generally we come accross a variety of pupils of different levels of knowledge and abilities in the class. In this case it is of paramount importance the motivating communication of the teacher and his or her style of teaching not only for the fact that the teacher imparts new indispensable knowledge to the pupils, but also the teacher communicates and talks to the pupils in order to get informed about their specific needs. The teacher also should consider the emotions of the pupils as one of the main pillars of sustinace for his adaption of the needed motivating communication taking in considerastion their respective time needed for the processing and assimilating of the knowledge. Thus we can conclude that the communication is not only the essence of the learning process but it is also a powerful means for the motivation and the direction of an individual or a group of pupils.

\section{References}

D. Truini" Guida alla comunicazione interpersonale e di gruppo" Angeli, Milano (1997).

Z.Dörnyei " The psychology of the language learner. Individual differences in second language acquisition", Routledge, New York \& London(2005)

Z.Dörnyei,E.Ushioda "Teaching and researching motivation" Longman, Harlow.(2010)

Kraja, Musa "Pedagogy", Mileniumi i ri, Tirane, (2006)

Newstead, Stephen "Learning and teaching", The Psychologist, May, (2003)

Papadhopulli Emil, Shimani Maksim "Assessment of pupils" Tirane (1996)

Christian Baylon \& Xavier Mignot - Communication. Logosa . Shkup 2004

Fullan,M.,(1991)"The new meaning ofeducation change, London CaselleU.K

Furlong,J.,\& Maynard,T.,(1995) Mentoring student teacher, London, Routledge,U.K

Musai, Bardhyl "fundamental skills of teaching. Eurolindja"; Tiranë (1996)

Beqja,Hamit"About educaiton"Tirane(1987)

Aliu,Mustafa"Biomotorics"Prishtine(1997)

Bozzaro,P"Psicologjia didattica apprendimento",Catania(2000)

TutkoT;Brunsë "Sport don't build character-They build characters" Sport contemporary Society,edD.Stanly Eitzen(New York:St Martin's Press)(1979)

Laura m.justice "Communication siences and disordes"Instock (2009)

Paul t.fogle "Essentials of communication sciences \& disorders"(2012)

Samy Molcho "Come il corpo cmunica senza parole"; (1997)

Giannelli L. "Sul valore comunicativo delle pause «vuote» nella narrazione e nel proverbio, nella prospettiva funzionale della frase" Roma, Bulzoni. (1992)

Casula C. "La comunicazione interpersonale", in Invernizzi E. (a cura di),

Relazioni pubbliche. Le competenze, le tecniche e i servizi di base, Milano, (2001),

Canepari L. "L'intonazione," Napoli, Liguori. (1985),

Argyle M. "Il corpo e il suo linguaggio", Bologna, Zanichelli. (1986).

Attili G. \& Ricci-Bitti P.E. "I gesti e i segni: la comunicazione non-verbale in psicologia e neuropsicologia clinica e il linguaggio dei segni nei sord"i, Roma,Bulzoni(1983).

Strati Antonio "La comunicazione organizzativa" Carocci(2013)

De Vincentiis Mauro "Professione portavoce. L'arte di comunicare il personaggio pubblico" (2012)

Cameron Milton" Ascoltando s'impara" Armenia (2012)

Giaccardi Chiara "La comunicazione interculturale nell'era digitale" II Mulino (2012)

P. Bertolini, "Dizionario di pedagogia e scienze dell'educazione" Zanichelli, Bologna (19969 
J. S. BRUNER, Verso una teoria dell'istruzione, Armando, Roma 1967,

Watlawick P. et al., Pragmatica della comunicazione umana. Astrolabio-Ubaldini Editore. Roma, (1971)

Arena G., La comunicazione di interesse generale, II Mulino, Bologna, 1995

http://www.edscuola.it/ 